\title{
Purkinje cell stripes and long-term depression at the parallel fiber-Purkinje cell synapse
}

\author{
Richard Hawkes ${ }^{1,2,3} *$ \\ ' Department of Cell Biology and Anatomy, University of Calgary, Calgary, AB, Canada \\ 2 Hotchkiss Brain Institute, University of Calgary, Calgary, AB, Canada \\ ${ }^{3}$ Genes and Development Research Group, Faculty of Medicine, University of Calgary, Calgary, AB, Canada
}

Edited by:

Richard Apps, University of Bristol, UK

Reviewed by:

Egidio D'Angelo, University of Pavia, Italy

Izumi Sugihara, Tokyo Medical and

Dental University, Japan

*Correspondence:

Richard Hawkes, Department of Cell Biology and Anatomy, Hotchkiss Brain Institute, and Genes and Development Research Group, Faculty of Medicine, University of Calgary, 3330 Hospital Drive NW, Calgary, AB T2N 4N1,

Canada

e-mail:rhawkes@ucalgary.ca
The cerebellar cortex comprises a stereotyped array of transverse zones and parasagittal stripes, built around multiple Purkinje cell subtypes, which is highly conserved across birds and mammals. This architecture is revealed in the restricted expression patterns of numerous molecules, in the terminal fields of the afferent projections, in the distribution of interneurons, and in the functional organization. This review provides an overview of cerebellar architecture with an emphasis on attempts to relate molecular architecture to the expression of long-term depression (LTD) at the parallel fiber-Purkinje cell (pf-PC) synapse.

\section{Keywords: zebrin II, phospholipase C $\beta 4$, Purkinje cell, stripes, long-term depression}

The general hypothesis explored in this review is that the elaborate molecular architecture of the cerebellar cortex has its counterpart in the compartmentation of function. In particular, many forms of synaptic plasticity have been identified in the cerebellar cortex (e.g., Hansel et al., 2001) - a network property that De Zeeuw et al. have called "distributed synergistic plasticity" (Gao et al., 2012). Both long-term depression (LTD) and long-term potentiation (LTP) have been identified, and these are expressed at multiple synapses-parallel-fiber to Purkinje cell, mossy fiber to granule cell, inhibitory interneuron to Purkinje cell ("rebound potentiation": e.g., Tanaka et al., 2013) etc.

By way of example, the review focuses on LTD at the parallel fiber-Purkinje cell (pf-PC) synapse. A brief consideration of its opposite -LTP-is also included. Other forms of Purkinje synaptic plasticity in the cerebellum are not included since so little is known of their relationship to the stripe architecture. Therefore, to set the stage the review begins with a brief overview of the patterning of the main players-Purkinje cells, climbing and mossy fiber afferents, and granule cells.

\section{OVERVIEW OF ZONE AND STRIPE ARCHITECTURE PURKINJE CELLS}

Several recent reviews have described the architecture of the adult cerebellar cortex (e.g., Apps and Garwicz, 2005; Apps and Hawkes, 2009; Ruigrok, 2011). In brief, a range of expression markers expressed in subsets of Purkinje cells have revealed an orthogonal matrix of transverse zones and parasagittal stripes (Figure 1). First, the cerebellar cortex is divided by transverse boundaries into transverse zones. These are most easily recognized in the vermis but appear to have their counterparts in the hemispheres as well. Each transverse zone is further subdivided into long narrow stripes that run parasagittally from rostral to caudal. The moststudied example is the expression pattern of zebrin II/aldolase C, which identifies a stereotyped array of zebrin II+ and zebrin II- stripes (e.g., Brochu et al., 1990; Hawkes and Gravel, 1991; Ahn et al., 1994; Hawkes and Herrup, 1995; Figures 1A, B). The combination of multiple such patterns adds up to a cerebellar cortex with several hundred distinct topographical units (e.g., Hawkes, 1997; Hawkes et al., 1997, 1999; Armstrong et al., 2000).

The Purkinje cell expression domains are reproducible between individuals to a remarkable level—individual stripes comprised of no more than 100 or so Purkinje cells are faithfully reproduced (e.g., the $\mathrm{P} 4 \mathrm{~b}+/ \mathrm{P} 5 \mathrm{a}+$ stripes in the hemispheres: Hawkes and Leclerc, 1987; Figures 1A, B). Indeed, although the size of a particular zone or stripe may be modified to suit the animal's mode of life a common ground plan is conserved across all mammals studied to date ( $\sim 30$ species-Sillitoe et al., 2005; Marzban and Hawkes, 2011) and is also found in birds (Pakan et al., 2007; Iwanuik et al., 2009; Marzban et al., 2010).

\section{AFFERENT PROJECTIONS}

Stripes of Purkinje cells are targets of specific afferent subsets during development and restrict their terminal fields in the adult, with the result that specific afferent subsets terminate in stripes. Studies over the past 25 years or so have shown that afferent terminal fields are precisely aligned with Purkinje cell stripes. These studies have combined immunocytochemistry for stripe antigens with anterograde tracing to 


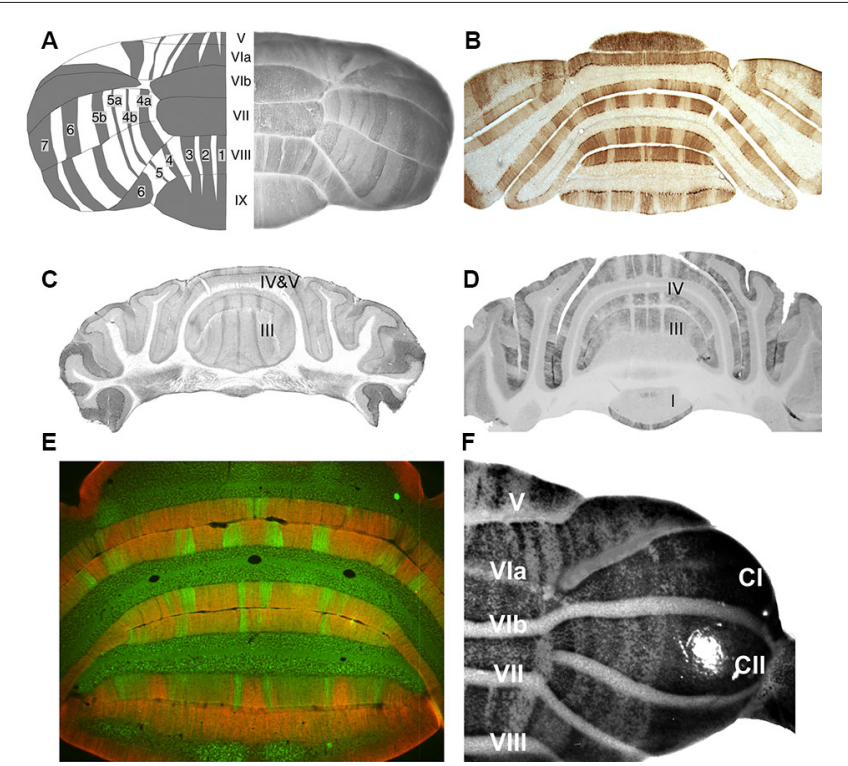

FIGURE 1 | Stripes in the adult mouse cerebellar cortex as revealed by various Purkinje cell subset markers. (A) On the right is a whole mount dorsal view of a hemicerebellum immunoperoxidase stained for zebrin II/aldolase $C$. On the left is a cartoon view: lobules are numbered with Roman numerals (V-IX); zebrin II+ stripes as 1-7 (Adapted from Furutama et al., 2010). (B) A transverse section through the posterior lobe immunoperoxidase stained by using anti-zebrin II (Adapted from Marzban et al., 2004). (C) A transverse section through the anterior lobe immunoperoxidase stained for phospholipase C $\beta 3$ (PLC $\beta 3$ ) (Adapted from Sarna et al., 2006). (D) A transverse section taken close to that in panel C, immunoperoxidase stained for PLCß4 (Adapted from Sarna et al., 2006).

(E) Transverse section through the posterior lobe double

immunofluorescence labeled for GABA type $B$ receptors $2\left(G A B A_{B} R 2\right)$ (red) and PLCB4 (green) (Adapted from Chung et al., 2008). (F) A whole mount dorsal view of a hemicerebellum from an $\mathrm{IP}_{3} \mathrm{R} 1 \mathrm{nls}$-lacZ transgenic mouse X-gal stained for transgene expression (Adapted from Furutama et al., 2010).

generate detailed topographical maps, in particular relating afferent terminal fields to zebrin II+/- stripes (e.g., climbing fibers-Gravel et al., 1987; Voogd et al., 2003; Sugihara and Shinoda, 2004; Voogd and Ruigrok, 2004; Sugihara and Quy, 2007 etc.; mossy fibers-Gravel and Hawkes, 1990; Akintunde and Eisenman, 1994; Ji and Hawkes, 1994; Armstrong et al., 2009; etc.). In some cases, molecular differences have also been demonstrated between afferent subsets. For example, mossy fibers that express somatostatin terminate on Purkinje cell stripes that express the small heat shock protein (HSP25; Armstrong et al., 2009), and climbing fibers immunoreactive for corticotropinreleasing factor (CRF) terminate selectively on zebrin II+ Purkinje cells (Sawada et al., 2008; see Section Corticotropin-releasing Factor).

Although striped patterns of Purkinje cell gene expression are aligned with stripes of afferent innervation, the formation and maintenance of stripes is not contingent upon afferent input: chemical or surgical afferent lesions do not alter the pattern (zebrin-Leclerc et al., 1988; Zagrebelsky et al., 1996, 1997; sphingosine kinase 1a-Terada et al., 2004; HSP25-Armstrong et al., 2001; L7/pcp2-Oberdick et al., 1993; etc.), and subtype phenotypes are expressed in slice and dissociated cerebellar cultures and after grafting the cerebellar anlage to an ectopic location (e.g., Wassef et al., 1990; Seil et al., 1995).

\section{GRANULE CELLS}

Purkinje cell stripe boundaries are also restriction boundaries for interneurons. Most prominent among these are the granule cells. First, the analysis of murine chimeras has identified a reproducible set of lineage boundaries within the granular layer that align with the transverse boundaries seen in the Purkinje cells (Hawkes et al., 1999). Multiple expression boundaries are also found at these locations in the adult and in the external granular layer during development (reviewed in Armstrong and Hawkes, 2000; Consalez and Hawkes, 2013). This strongly suggests that different granule cell lineages exploit the underlying Purkinje cell zonal architecture as the external granular layer spreads to cover the embryonic cerebellar anlage. Secondly, in the adult granular layer a complex array of patches and stripes can be revealed (e.g., nitric oxide (NO) synthase or its surrogate, reduced nicotinamide adenine dinucleotide phosphate (NADPH) diaphorase: Hawkes and Turner, 1994; Schilling et al., 1994; Ozol and Hawkes, 1997; Hawkes et al., 1998). These also align with the Purkinje cell architecture. It is difficult to credit that these represent cell autonomous properties of the granule cells, given the challenges such a model would present for the targeting of granule cell migration and settling, so it is more likely that the expression patterns are secondary to the local environment (e.g., Purkinje cells or mossy fibers).

\section{FUNCTIONAL CORRELATES OF STRIPES}

Given that pretty much everything in the anatomy of the cerebellar cortex is stripy, it should be unsurprising that similar compartmentation is seen by using functional mapping. First, parasagittal stripes are seen in electrophysiological recordings from the cerebellar cortex-the 12 A-D2 longitudinal zones and microzones (e.g., Oscarsson, 1979; for an account of the baroque terminology of cerebellar architecture, see Apps and Hawkes, 2009) — and these align with, and are likely the same thing as, the striped domains of differential gene expression. Similarly, optical imaging of the cerebellar cortex also reveals a parasagittally striped functional organization (e.g., Chen et al., 1996; Ebner et al., 2005, 2012; Gao et al., 2006). In contrast, recordings of tactile receptive fields in the hemispheres apparently reveal a somewhat different organization-a complex but reproducible array of functional patches responsive to different stimulus sites-vibrissae, lips, teeth etc., ("fractured somatotopy": reviewed in Welker, 1987). However, when the tactile receptive field boundaries and antigenic boundaries are compared, a reproducible alignment is found (e.g., Chockkan and Hawkes, 1994; Hallem et al., 1999) that is consistent with the evidence cited above that mossy fiber afferent terminal fields show stripe restriction.

Different Purkinje cell stripes receive climbing fibers from different sources. Consistent with this topography, Paukert et al. (2010) recently showed that climbing fibers that terminate on zebrin II+ Purkinje cells release more glutamate per action potential than do those terminating in zebrin II- stripes. As a result, climbing fiber-mediated excitatory postsynaptic potentials in 
Purkinje cells decay more slowly in the zebrin II+ stripes, and thus longer-duration complex spikes are triggered. The implication is that prolonged climbing fiber-induced depolarization of Purkinje neurons in zebrin II+ stripes should preferentially enhance $\mathrm{Ca}^{2+}$ influx and thereby facilitate activity-dependent changes in the strength of both climbing and parallel fiber synapses (Hansel et al., 2001; Safo et al., 2006; Carey and Regehr, 2009; Mathy et al., 2009).

Finally, Wadiche and Jahr $(2001,2005)$ have shown that Purkinje cells in zebrin II+/- stripes express different complements of excitatory amino acid transporters (EAATs), some of which are more effective than others. As a result, regional differences in glutamate transporter expression affect the degree of metabotropic glutamate receptor (mGluR1) stimulation (see Section Glutamate Re-uptake).

\section{MOLECULAR CORELATES OF LONG-TERM DEPRESSION AT THE PARALLEL FIBER-PURKINJE CELL SYNAPSE}

The functional differences between stripes derive in two ways. On the one hand they reflect differences in connectivity (i.e., the striped organization of the olivocerebellar and mossy fiber projections). On the other hand-and central to what followsdifferent stripes display distinctly different intrinsic properties, notably a variety of different forms of synaptic plasticity (e.g., reviewed in Hansel et al., 2001). The hypothesis explored in this review is that the specificity of the afferent topography together with the molecular heterogeneity of the granule cells and Purkinje cells constitutes a substrate for multiple plastic adaptations of the pf-PC synapse. What follows focuses on LTD at the pf-PC synapse as an exemplar.

Purkinje cells receive 2 glutamatergic excitatory inputs, one from mossy fibers via pf-PC synapses on dendritic spines and another from climbing fibers onto the dendritic shafts. Conjunctive stimulation of the parallel fiber and climbing fiber pathways (1-4 Hz for 1-10 $\mathrm{min}$ ) results in a long-lasting depression of transmission at the pf-PC synapse (e.g., recently reviewed in Vogt and Canepari, 2010; Finch et al., 2012; an excellent history is provided in Kano et al., 2008). LTD has often been evoked as a model of cerebellar motor learning, but recent studies cast doubt on this (Schonewille et al., 2011; Gao et al., 2012).

LTD at the pf-PC synapse is quantitatively different between stripes: it is easier to induce pf-PC synapse LTD in zebrin IIthan in zebrin II+ Purkinje cells (Wadiche and Jahr, 2001). Little is known of the molecular basis for differences in LTD across stripes but it is striking that many molecules whose expression is in stripes are associated with the putative pathways leading to LTD (Table 1).

An influential model of the molecular basis of LTD at the pf-PC synapse, due to Ito (e.g., reviewed in Ito, 1984, 1989, 2002), is summarized in a simplified fashion in Figure 2. In brief, conjunctive glutamate release from parallel fiber and climbing fiber terminals acts through mGluR1 to activate several parallel intracellular signaling pathways - in particular, one via phospholipase $\mathrm{C}$ (PLC) and diacylglycerol (DAG) to protein kinase $\mathrm{C}$ (PKC), and another via inositol triphosphate $\left(\mathrm{IP}_{3}\right)$. The downstream consequence is the internalization of AMPA ( $\alpha$-amino-3-hydroxy-5-methyl-4-isoxazolepropionic acid)-sensitive glutamate receptors (AMPAR), and consequent synaptic desensitization. NO and CRF play supporting roles. It is instructive to examine the expression patterns of the different players in this pathway.

\section{SYNAPTIC MARKERS}

First of all a reproducible pattern of stripes is revealed in the molecular layer of the cerebellar cortex by using immunocytochemistry for the synaptic vesicle protein synaptophysin (Hawkes et al., 1985), with stripes of higher expression alternating with those of lower expression, both in the granular layer associated with mossy fiber synaptic glomeruli and in the molecular layer, associated primarily with pf-PC synapses (Hawkes et al., 1985; Leclerc et al., 1989). The interpretation of the observation is less obvious-does stronger staining reflect more antigen per vesicle, antibody access, more vesicles per synapse, a higher Purkinje cell spine density ...? Appropriate comparisons with the expression patterns of other synaptic markers that might resolve this question have not been reported. A patchy/striped arrangement of mossy fiber terminals in the granular layer is reported with other presynaptic markers, but in these cases the expression in the molecular layer appears to be uniform (e.g., dysbindin-Sillitoe et al., 2003; neuronal nitric oxide synthase (nNOS); see Section Nitric Oxide). A uniform distribution in the molecular layer may be misleading in that differential expression of granule cell markers is easier to discern in the granular layer, where the somata are segregated into stripes and clusters, than in the molecular layer where the

\begin{abstract}
Table 1 | A list of the synaptic molecules with striped expression patterns referred to in the text; whether they are preferentially expressed in zebrin II+ (zIl+) or zebrin II- (zIl-) stripes (or a mixture of both); and pertinent citations.
\end{abstract}

\begin{tabular}{|c|c|c|}
\hline Molecule & $\begin{array}{c}\text { Stripe } \\
\text { preference }\end{array}$ & Citations \\
\hline Synaptophysin & $z||+|z| \mid-$ & $\begin{array}{l}\text { Hawkes et al. (1985); Leclerc } \\
\text { et al. (1989) }\end{array}$ \\
\hline Dysbindin & $z \mid l+/ z \|-$ & Sillitoe et al. (2003) \\
\hline nNOS/NADPHd & $z||+/ z||-$ & $\begin{array}{l}\text { Yan et al. (1993); Hawkes and } \\
\text { Turner (1994); } \\
\text { Schilling et al. (1994); } \\
\text { Baader and Schilling (1996) }\end{array}$ \\
\hline Neuroplastin & zll- & Marzban et al. (2003) \\
\hline mGluR1b & $z l l-$ & Mateos et al. (2001) \\
\hline EAAT4 & $z l l+$ & Dehnes et al. (1998) \\
\hline $\begin{array}{l}\text { NMDA receptor } \\
\left(\mathrm{NR} 2 \mathrm{C}^{\text {nlacZ }}\right)\end{array}$ & $z l l-$ & Karavanova et al. (2007) \\
\hline CRF & $z l l+$ & Sawada et al. (2008) \\
\hline PLC $\beta 3$ & zll+ & Sarna et al. (2006) \\
\hline PLC $\beta 4$ & zll- & Sarna et al. (2006) \\
\hline $\mathrm{IP}_{3} \mathrm{R}$-nls-LacZ & $z l l+$ & Furutama et al. (2010) \\
\hline $\mathrm{PKC} \delta$ & $z l l+$ & Barmack et al. (2000) \\
\hline $\mathrm{GABA}_{\mathrm{B}} \mathrm{R} 2$ & $z l l+$ & $\begin{array}{l}\text { Albin and Gilman (1989); } \\
\text { Luján and Shigemoto (2006); } \\
\text { Chung et al. (2008) }\end{array}$ \\
\hline Neurogranin & zll- & Larouche et al. (2006) \\
\hline PEP-19 & $?$ & Wassef et al. (1992) \\
\hline
\end{tabular}




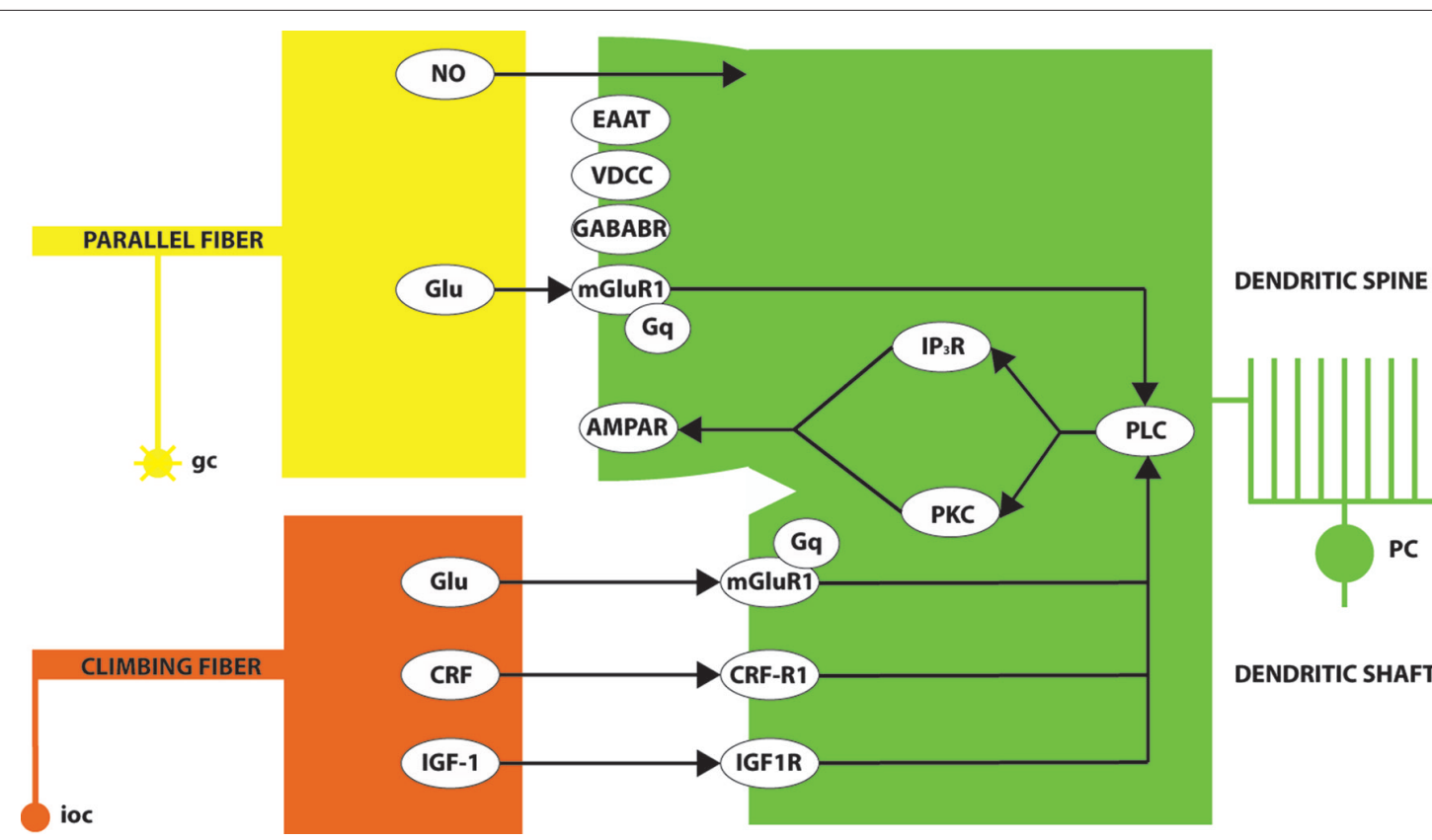

FIGURE 2 | A simplified model of some of the signaling pathways leading to LTD of the pf-PC synapse. Conjunctive glutamate (Glu) release at the granule cell $(\mathrm{gc}) /$ parallel fiber synapse on the Purkinje cell (PC) dendritic spine and the climbing fiber (from inferior olivary cells: ioc) synapses on the dendritic shaft activates the metabotropic glutamate receptor (mGluR1). Glutamate signaling across the synaptic cleft is modulated by excitatory amino acid transporters (EAAT). A signaling pathway via Gq proteins activates PLC. In turn, PLC signals via both the inositol triphosphate receptor $\left(\mathrm{P}_{3} \mathrm{R}\right)$ and protein kinase $\mathrm{C}(\mathrm{PKC})$. The upshot is the internalization of synaptic AMPA receptors and consequent LTD. The overall process is also modulated by various other signals including: presynaptic nitric oxide release (NO); the binding of corticotropin-releasing factor (CRF) to its receptor (CRF-R1) and insulin-like growth factor (IGF)-1 binding to its receptor (IGF-1R), both of which signal via PLC; signaling via postsynaptic $G A B A_{B} R$; and calcium influx through voltage-dependent calcium channels (VDCCs). long parallel fiber trajectories extensively overlap and smooth out different expression levels from different granule cell populations.

Structural synaptic proteins are also differentially expressed. For example, a prominent striped expression pattern is revealed by immunocytochemical staining for the postsynaptic membrane glycoprotein neuroplastin (Marzban et al., 2003; note-in the hippocampus, neuroplastin has been linked to the inhibition of LTP; Empson et al., 2006). High levels of neuroplastin expression are preferentially associated with the zebrin II- Purkinje cell stripes.

\section{GLUTAMATE RECEPTORS}

Glutamate released into the synaptic cleft at both the climbing fiber and the pf-PC synapse binds to three types of glutamate receptor in the postsynaptic membrane-metabotropic (mGluR), GluR $\delta 2$ and AMPAR. mGluRs are G protein-coupled receptors with 7 transmembrane segments that do not form ion channels but rather signal via intracellular chemical messenger systems. Eight genes coding for different subtypes of mGluRs have been identified, seven of which are expressed in the cerebellum. In particular, Purkinje cell mGluR1 is localized in the peri- and extra-synaptic membranes. It is functionally coupled to PLC through which it modulates the $\mathrm{IP}_{3}$ $(1,4,5) / \mathrm{Ca} 2+$ signaling pathway and plays a key role in the induction of pf-PC LTD (reviewed in Knöpfel and Grandes, 2002).
There are at least $4 \mathrm{mGluR} 1$ splice variants with differing subcellular and cellular distributions (mGluRla-d: e.g., Conn and Pin, 1997). In the case of mGluR1b in the cerebellum, expression is striped in the molecular layer and co-located with zebrin IIstripe markers (Mateos et al., 2001). mGluRla is also located in the Purkinje cell dendritic spine (e.g., Mateos et al., 2000) but whether or not there is an mGluR subtype restricted to the zebrin II+ Purkinje cell dendritic spines is not known.

GluR $\delta 2$ is also highly expressed in cerebellar Purkinje cells and is localized specifically to pf-PC synapses (Araki et al., 1993; reviewed in Hirano, 2006). GluR $\delta 2$ neither binds glutamate nor conducts current but rather regulates mGluR1-mediated synaptic transmission via PKC $\gamma$ (e.g., Kato et al., 2012). Loss-of-function mutations in GluR $\delta 2$ result in multiple defects including impairment of LTD (Kashiwabuchi et al., 1995). There is no evidence that its expression is stripe-restricted (gain-of-function mutation of the GluR $\delta 2$ gene in the lurcher mouse $\left(G_{r i d}^{L c} /+\right)$ results in striped Purkinje cell degeneration (Zuo et al., 1997; reviewed in Armstrong et al., 2011) but this likely reflects differential sensitivity to the insult rather than selective GluR $\delta 2$ expression).

\section{GLUTAMATE RE-UPTAKE}

The time that glutamate resides in the synaptic cleft, and hence is available for receptor binding, is governed by EAAT. In particular, EAAT4 has been implicated at the pf-PC synapse. It is therefore striking that the expression of EAAT4 is different from stripe 
to stripe with high levels associated with the zebrin II+ stripes (Dehnes et al., 1998). As a result, regional differences in glutamate transporter expression affect the degree of mGluR1 receptor stimulation, with the result that pf-PC LTD is dampened in Purkinje cells expressing high levels of EAAT4 (= zebrin II+; Wadiche and Jahr, 2005).

\section{CALCIUM INFLUX}

One consequence of mGluR1 activation is $\mathrm{Ca}^{2+}$ influx via VDCC in the postsynaptic dendritic membrane. There is no evidence that VDCCs are expressed differentially by Purkinje cell subsets (As for the lurcher mouse, it has been shown that a mutation of the VDCC $\alpha 1$ a channel in the tottering mouse (Cacnala $a^{\text {tg }}$ ) results in the selective Purkinje cell death of the zebrin II- Purkinje cell subset, but again the evidence suggests that this is due to differential sensitivity to an abnormal $\mathrm{Ca}^{2+}$ influx rather than restricted expression of the $\alpha$ la channel; Fletcher et al., 1996).

The downstream response to dendritic $\mathrm{Ca}^{2+}$ influx is modulated by calpacitins, notably the 2 Purkinje cell proteins PEP-19 and neurogranin/RC3. Sutcliffe and colleague have proposed that calpacitins regulate calmodulin availability in dendritic spines and thus regulates their ability to amplify the mobilization of $\mathrm{Ca}^{2+}$ in response to metabotropic glutamate receptor stimulation, releasing calmodulin rapidly in response to large influxes of $\mathrm{Ca}^{2+}$ and slowly in response to small increases. This action is inhibited by PKC-mediated phosphorylation (reviewed in Gerendasy and Sutcliffe, 1997; Díez-Guerra, 2010). $\alpha$-Calmodulin kinase KII is also shown to be required for LTD at the pf-PC synapse (Hansel et al., 2006). Neurogranin knockout mice show deficits in the induction of hippocampal LTP (e.g., Pak et al., 2000) but no cerebellar phenotype is reported. On the other hand, the much more abundant PEP19 is directly implicated: in the PEP19 null mouse both motor learning and pf-PC LTD are impaired (Wei et al., 2011). During cerebellar development, both PEP19 (Wassef et al., 1992) and neurogranin (Larouche et al., 2006) expression is restricted to Purkinje cell subsets. However, in the adult PEP19 expression is uniformly expressed by all Purkinje cells (Mugnaini et al., 1987) whereas neurogranin has disappeared (Larouche et al., 2006), so any significance for patterned LTD at the adult pf-PC synapse is doubtful.

\section{NITRIC OXIDE}

In addition to releasing glutamate, parallel fibers also release NO. NO acts through inhibition of protein phosphatases in the Purkinje cell dendritic spine and thus enhance AMPAR phosphorylation. LTD is abolished in transgenic mice lacking nNOS (Lev-Ram et al., 1997). There is clear evidence of different stripes of nNOS in the granular layer of the cerebellar cortex (e.g., Yan et al., 1993; Hawkes and Turner, 1994; Schilling et al., 1994; Baader and Schilling, 1996). Similar striping is harder to discern in the molecular layer, perhaps obscured by the overlapping parallel fiber populations. The nNOS pathway is activated via Nmethyl-D-aspartate (NMDA)-type glutamate receptors located at the pf-PC synapse (and/or located in the presynaptic terminals of inhibitory interneurons; Shin and Linden, 2005). Functional NMDA receptors are also expressed at climbing fiber-PC synapses, and channel blocking inhibits LTD (Piochon et al., 2010).
It is noteworthy that NMDA receptor expression, as revealed by an NRC2 subunit knock-in mouse (NR2 $\left.\mathrm{C}^{\text {nlacZ }}\right)$, reveals stripes of granule cells similar to those revealed by PLC $\beta 4$ expression (= zebrin II-; Karavanova et al., 2007). There is no evidence that Purkinje cell NMDA receptors are expressed in stripes.

\section{CORTICOTROPIN-RELEASING FACTOR}

Glutamate release and binding to mGluR1 is also the first step in signaling via the climbing fiber pathway. In parallel to glutamate release, climbing fibers also secrete CRF (Barmack and Young, 1990), which plays a permissive role in LTD that is probably mediated through PKC (Miyata et al., 1999). However, not all climbing fibers express CRF. Whole mount immunocytochemistry shows that CRF is restricted to (or is expressed at higher levels in) a striped subset of climbing fiber terminals that terminate in zebrin II+ Purkinje cell stripes (mouse-Sawada et al., 2008). However, the significance of this may not be straightforward as previous studies reported uniform CRF expression (e.g., cat-Cummings, 1989) or expression differences between lobules but not in the form of stripes (e.g., developing mouse-Overbeck and King, 1999). There is no evidence that G-protein coupled CRF receptor (CRFR1) expression is similarly striped (e.g., Allen Brain Atlas).

\section{INSULIN-LIKE GROWTH FACTOR 1}

As well as releasing CRF, climbing fiber synapses also store and release IGF-1 (Torres-Aleman et al., 1994). It is not known if IGF-1 or its receptor tyrosine kinase (IGF1R) is expressed in stripes in the adult cerebellum (in general in the brain IGF1R is broadly expressed-it is the ligands that show regional restriction: e.g., reviewed in D'Ercole et al., 1996). During early postnatal development, IGF-1 is also expressed in a zebrin II- Purkinje cell subset, where it acts to block apoptosis (Croci et al., 2011), but it is unclear whether selective expression is retained in the adult.

\section{PHOSPHOLIPASE C $\beta$}

mGluR1 signals via the Gq subclass of G-proteins to PLC $\beta$ (reviewed in Knöpfel and Grandes, 2002). There are four PLC $\beta$ isoforms, encoded by distinct genes (PLCß1-4; Bahk et al., 1994). Strikingly, PLC $\beta 3$ and PLC $\beta 4$ are expressed by distinct, nonoverlapping subsets of Purkinje cells. PLC $\beta 3$ is confined to the zebrin II+ Purkinje cell subset (Figure 1C) and PLC $\beta 4$ expression is coextensive with the zebrin II- Purkinje cell subset (Figures 1D, E; Sarna et al., 2006; Marzban et al., 2007) (Unexpectedly, a small subset of zebrin II+ Purkinje cell stripes in the nodular zone of the mouse cerebellum $(\sim$ lobules IX and X)—those that express HSP25-is reproducibly immunonegative for both PLC $\beta 3$ and PLC $\beta 4$ (Sarna et al., 2006) — the implication of this is unclear).

\section{PHOSPHOLIPASE A}

Parallel to the PLC $\beta$ pathway, there is also a signaling pathway via phospholipase A (PLA) - in particular, the PLA2 isoform: e.g., Linden, 1995; Le et al., 2010), which acts to break down phospholipids into arachidonic acid, a potent activator of PK C $\gamma$ (e.g., Shearman et al., 1989). At least 20 PLA2 isoforms have been identified, three of which have been reported in Purkinje cells (cPLA2 $\alpha$, sPLA2IIA, and iPLA2; Shirai and Ito, 2004). There is 
no evidence that any of these is restricted to a particular Purkinje cell subset.

\section{INOSITOL $(1,4,5)$ TRIPHOSPHATE RELEASE}

Two signaling pathways leading to LTD lie downstream of PLC. The first involves $\mathrm{IP}_{3}$ release from intracellular stores to bind to its receptor on the endoplasmic reticulum $\left(\mathrm{IP}_{3} \mathrm{R}\right.$; e.g., Furuichi et al., 1989; Maeda et al., 1989). The cerebellar distribution of $\mathrm{IP}_{3} \mathrm{R}$ has recently been reported in a transgenic mouse in which the $\mathrm{IP}_{3} \mathrm{R}$ promoter was fused to a $\beta$-galactosidase reporter and a nuclear localization signal (IP ${ }_{3}$ R1nls-lacZ; Furutama et al., 1996, 2010; Figure 1F). Transgene expression in the heterozygote reveals a striking array of Purkinje cell stripes that can be traced continuously through embryogenesis through to adulthood. In general, $\mathrm{IP}_{3} \mathrm{R} 1 \mathrm{nls}-\mathrm{lac} Z$ transgene expression is restricted to the zebrin II+ Purkinje cell subset. The extent to which this distribution reflects any feature of the true restriction of the receptor-perhaps developmentally — or is a transgene artifact (due to the transgene insertion, promoter truncation, enhancer trapping, etc.), is questionable. Immunocytochemistry with antibodies against $\mathrm{IP}_{3} \mathrm{R}$ do not show Purkinje cell stripes (e.g., Mignery et al., 1989).

\section{PROTEIN KINASE C (PKC)}

An additional second-messenger signaling pathway between glutamate release and the induction of LTD goes via the generation of DAG by PLC, which in turn activates PKC (Crépel and Krupa, 1988; for a general review of PKC, see Newton, 1995). There are seven PKC subtypes-three $(\alpha, \beta$ and $\gamma)$ activated in a $\mathrm{Ca}^{2+} / \mathrm{DAG}-$ dependent manner and $4(\delta, \epsilon, \eta$ and $\theta) \mathrm{Ca}^{2+}$-independent (reviewed in Tanaka and Nishizuka, 1994). Activation of $\mathrm{Ca}^{2+}$ dependent PKC is necessary for induction of LTD at the pf-PC synapse (e.g., Ito, 1989, 2002; Daniel et al., 1998). LTD induction at the pf-PC synapse is blocked by the intracellular application of PKC inhibitors in Purkinje cells (Linden and Connor, 1991). De Zeeuw et al. (1998) constructed a transgenic mouse in which a Purkinje cell-specific promoter (pcp2-L7) was used to target the expression of a broad-spectrum PKC inhibitor (the pseudosubstrate PKC[19-31]) and thereby showed that PKC activation in the Purkinje cell is a prerequisite for the induction of LTD. None of the $\mathrm{Ca}^{2+} / \mathrm{DAG}$-dependent PKC isoforms is expressed selectively by a Purkinje cell subset (e.g., Barmack et al., 2000).

The role(s), if any, of the four $\mathrm{Ca}^{2+}$-independent PKCs in LTD induction is unclear. However, they deserve attention here because while most PKC isoform distributions are uniform across the molecular layer the one exception is PKC $\delta$, whose expression in the nodular zone of the rat reveals a reproducible striped expression pattern with higher levels in the zebrin II+ stripes (Barmack et al., 2000). Furthermore, experimental manipulation of the cerebellar afferent inputs by labyrinthectomy demonstrated an activity-dependent targeting of the PKC $\delta$ isoform to the pfPC synapse (Barmack et al., 2001). PKC $\delta$ has been implicated in hippocampal LTP (e.g., Kim et al., 2013) but no specific role in cerebellar LTD is known.

\section{GABA $_{B}$ RECEPTORS}

LTD at the pf-PC synapse is also modulated by an unusual form of $\gamma$-aminobutyric acid (GABA) receptor signaling. In the adult cerebellum $\mathrm{GABA}_{\mathrm{B}}$ Rs are predominantly located perisynaptically at the dendritic spines of Purkinje cells (e.g., Turgeon and Albin, 1993; Kaupmann et al., 1997; Bischoff et al., 1999; Kulik et al., 2002; Fritschy et al., 2004; Luján and Shigemoto, 2006). Both $\mathrm{GABA}_{\mathrm{A}}$ (reviewed in Fritschy and Panzanelli, 2006) and $G A B A_{B}$ receptor classes are expressed in the cerebellum but only $G_{A B} A_{B}$ Rs have been implicated in pf-PC LTD. $G A B A_{B}$ Rs are G-protein-coupled receptors formed as heteromers of 2 subunits $\left(\mathrm{GABA}_{\mathrm{B}} \mathrm{R} 1 / 2\right.$; Marshall et al., 1999; Möhler and Fritschy, 1999). Postsynaptic $\mathrm{GABA}_{\mathrm{B}} \mathrm{R}$ signaling enhances LTD (Tabata et al., 2004; Kamikubo et al., 2007), possibly as a $\mathrm{Ca}^{2+}$-dependent cofactor of mGluR1 signaling. The role of $\mathrm{GABA}_{B}$ Rs in the modulation of LTD is unconventional in that it does not require GABA. Rather, extracellular $\mathrm{Ca}^{2+}$ binds to the $\mathrm{GABA}_{\mathrm{B}} \mathrm{R}$ and constitutively increases the glutamate sensitivity of mGluR1 (Tabata et al., 2004). The role of $G A B A_{B} R$ in LTD is relevant for the present discussion because immunocytochemistry for $G_{A B A} R 2$ shows a strong restriction of receptor immunoreactivity to the zebrin II+ stripes (Albin and Gilman, 1989; Luján and Shigemoto, 2006; Chung et al., 2008; Figure 1E).

\section{AMPA RECEPTORS}

The ultimate downstream target of PLC signaling, via both PKC and $\mathrm{IP}_{3} \mathrm{R}$, is the phosphorylation (via both PKC and Src-family protein tyrosine kinases-e.g., Tsuruno et al., 2008) of postsynaptic AMPA receptors (AMPAR; Ito, 1984; Crépel and Krupa, 1988; Hirano, 1991; Linden et al., 1991; Matsuda et al., 2000; Tsuruno et al., 2008; etc.). AMPAR kinetics, agonist affinity and unitary conductances are unchanged by phosphorylation (Linden, 2001) but rather there results a reduction in AMPAR number due to enhanced endocytosis (Matsuda et al., 2000), which is dependent on phosphorylation at ser-880 in the AMPAR GluR2 subunit (Chung et al., 2003; reviewed in Shin and Linden, 2005). There is no evidence of selective expression of either Src kinases or AMPAR by Purkinje cell subsets.

\section{MOLECULAR CORELATES OF LONG-TERM POTENTIATION AT THE PARALLEL FIBER-PURKINJE CELL SYNAPSE}

The opposite process-LTP-countermands LTD at the pf-PC synapse. This endows the synapse with bidirectional plasticity (Lev-Ram et al., 2002; Coesmans et al., 2004). Postsynaptic LTP is induced by parallel fiber stimulation ( $1 \mathrm{~Hz}$ for $5 \mathrm{~min}$ : Lev-Ram et al., 2002, 2003). The signaling pathways implicated resemble those previously identified for hippocampal LTP (e.g., Jörntell and Hansel, 2006). Stimulation causes $\mathrm{Ca}^{2+}$ influx via voltagesensitive channels, which activates several calmodulin-activated protein phosphatases (PP1, PP2A and PP2B; Lev-Ram et al., 2003; Coesmans et al., 2004; Belmeguenai and Hansel, 2005; Schonewille et al., 2010). In turn, this results in enhanced AMPA receptor insertion into the postsynaptic membrane (a process dependent upon NO—Huang et al., 2005; Kakegawa and Yuzaki, 2005). It is not known if this form of pf-PC LTD or the molecules in the downstream pathways are differentially expressed between Purkinje cell subsets.

In contrast, another apparent manifestation of pf-PC LTP has a close relationship to cerebellar stripes. This instance comes from the flavoprotein autofluorescence imaging of cerebellar activity 
by Ebner and colleagues (e.g., Wang et al., 2009, 2011; Ebner et al., 2012). By stimulating mouse cerebellar cortex by using a paradigm that induces LTP at pf-PC synapses, an array of long-latency patches was revealed that aligns with the zebrin II+ Purkinje cell stripes and shows robust LTP. This form of LTP is mGluR1-dependent and blocked by application of PLC $\beta$ and ryanodine receptor inhibitors. This is pertinent because both mGluR1 receptor subtypes (Mateos et al., 2001; III.ii above) and PLC $\beta$ isoforms (Sarna et al., 2006; III.vii. above) are expressed in stripes. How this expression of LTP relates to that described above, is unclear.

\section{CONCLUSIONS}

In this review, LTD at the pf-PC synapse has been used as an example of a correlation between the molecular architecture of the cerebellar cortex and the specialization of cerebellar function. To recapitulate, the data show two things: first, LTD is manifested differently in different stripes; and secondly, some of the molecules implicated in the LTD signaling pathways also show expression patterns restricted to stripes, ranging from convincing (e.g., mGluR1b, EAAT4, PLC $\beta 3$, PLC $\beta 3 / 4$, GABA $_{B}$ R2) to intriguing (e.g., nNOS, CRF), to being of marginal significance at best (e.g., IP ${ }_{3}$ R; IGF-1; PKC $\delta$ : Table 1). While this review has focused on one aspect of cerebellar function as an exemplar-LTD at the pf-PC synapse-it would be surprising if the molecular architecture were not similarly customized to serve other cerebellar functions. The evidence that LTP at the pf-PC synapse may also vary across stripes is also briefly reviewed. The conclusion is thus that cerebellar function has evolved to accommodate the different requirements of multiple, parallel afferent and efferent pathways, by customizing key molecular constituents. For example, on the afferent side Purkinje cell stripes receive mossy fiber pathway input from multiple sources and with very different firing patterns - have pf-PC synapses specialized to accommodate this? Likewise on the efferent side, do different cortical receiving areas require different LTD kinetics? Another consideration is that perhaps stripes work as zebrin $\mathrm{II}+/-$ pairs. One hint that this might be the case comes from the studies of optic flow in the pigeon cerebellum by Graham and Wylie (2012), which show that Purkinje cells in zebrin II+/- stripe pairs all respond best to the same pattern of optic flow. Given that climbing fibers onto zebrin II+ Purkinje cell stripes release more glutamate than those onto zebrin II- stripes (e.g., Paukert et al., 2010) it may be that both slow and fast adapting stripes work in concert as the fundamental functional unit in the cerebellar cortex.

\section{REFERENCES}

Ahn, A. H., Dziennis, S., Hawkes, R., and Herrup, K. (1994). The cloning of zebrin II reveals its identity with aldolase C. Development 120, 2081-2090.

Akintunde, A., and Eisenman, L. M. (1994). External cuneocerebellar projections and Purkinje cell zebrin II bands: a direct comparison of parasagittal banding in the mouse cerebellum. J. Chem. Neuroanat. 7, 75-86. doi: 10.1016/08910618(94)90009-4

Albin, R. L., and Gilman, S. (1989). Parasagittal zonation of GABA-B receptors in molecular layer of rat cerebellum. Europ. J. Pharmacol. 173, 113-114. doi: 10. 1016/0014-2999(89)90014-9

Apps, R., and Garwicz, M. (2005). Anatomical and physiological foundations of cerebellar information processing. Nat. Rev. Neurosci. 6, 297-311. doi: 10. $1038 / \mathrm{nrn} 1646$
Apps, R., and Hawkes, R. (2009). Cerebellar cortical organization: a one-map hypothesis. Nat. Rev. Neurosci. 10, 670-681. doi: 10.1038/nrn2698

Araki, K., Meguro, H., Kushiya, E., Takayama, C., Inoue, Y., and Mishina, M. (1993). Selective expression of the glutamate receptor channel delta 2 subunit in cerebellar Purkinje cells. Biochem. Biophys. Res. Commun. 3, 1267-1276. doi: 10. 1006/bbrc.1993.2614

Armstrong, C. L., Chung, S. H., Armstrong, J. N., Hochgeschwender, U., Jeong, Y. G., and Hawkes, R. (2009). A novel somatostatin-immunoreactive mossy fiber pathway associated with HSP25-immunoreactive Purkinje cell stripes in the mouse cerebellum. J. Comp. Neurol. 517, 524-538. doi: 10.1002/cne. 22167

Armstrong, C. L., Duffin, C. A., McFarland, R., and Vogel, M. W. (2011). Mechanisms of compartmental Purkinje cell death and survival in the lurcher mutant mouse. Cerebellum 10, 504-514. doi: 10.1007/s12311-010-0231-4

Armstrong, C. L., and Hawkes, R. (2000). Pattern formation in the cerebellar cortex. Biochem. Cell Biol. 78, 551-562. doi: 10.1139/000-071

Armstrong, C. L., Krueger-Naug, A. M., Currie, R. W., and Hawkes, R. (2000). Constitutive expression of the $25 \mathrm{kDa}$ heat shock protein Hsp25 reveals novel parasagittal stripes of Purkinje cells in the adult mouse cerebellar cortex. J. Comp. Neurol. 416, 383-397. doi: 10.1002/(sici)1096-9861(20000117) 416:3<383::aid-cne9>3.0.co;2-m

Armstrong, C. L., Krueger-Naug, A. M., Currie, R. W., and Hawkes, R. (2001). Expression of heat-shock protein Hsp25 in mouse Purkinje cells during development reveals novel features of cerebellar compartmentation. J. Comp. Neurol. 429, 7-21. doi: 10.1002/1096-9861(20000101)429:1<7::aid-cne2>3.0.co;2-q

Baader, S. L., and Schilling, K. (1996). Glutamate receptors mediate dynamic regulation of nitric oxide synthase expression in cerebellar granule cells. $J$. Neurosci. 16, 1440-1449.

Bahk, Y. Y., Lee, Y. H., Lee, T. G., Seo, J., Ryu, S. H., and Suh, P. G. (1994). Two forms of phospholipase C-beta 1 generated by alternative splicing. J. Biol. Chem. 269, 8240-8245.

Barmack, N. H., Qian, Z. Y., Kim, H. J., and Yoshimura, J. (2001). Activitydependent distribution of protein kinase C-delta within rat cerebellar Purkinje cells following unilateral labyrinthectomy. Exp. Brain Res. 141, 6-20.

Barmack, N. H., Qian, Z., and Yoshimura, J. (2000). Regional and cellular distribution of protein kinase C in rat cerebellar Purkinje cells. J. Comp. Neurol. 427, 235-254. doi: 10.1002/1096-9861(20001113)427:2<235::aid-cne6>3.0.co;2-6

Barmack, N. H., and Young, W. S. (1990). Optokinetic stimulation increases corticotropin-releasing factor mRNA in inferior olivary neurons of rabbits. $J$. Neurosci. 10, 631-640.

Belmeguenai, A., and Hansel, C. (2005). A role for protein phosphatases 1, 2A and 2B in cerebellar long-term potentiation. J. Neurosci. 25, 10768-10772. doi: 10. 1523/jneurosci.2876-05.2005

Bischoff, S., Leonhard, S., Reymann, N., Schuler, V., Shigemoto, R., Kaupmann, K., et al. (1999). Spatial distribution of $\mathrm{GABA}_{B} \mathrm{R} 1$ receptor mRNA and binding sites in the rat brain. J. Comp. Neurol. 412, 1-16. doi: 10.1002/(sici)10969861(19990913)412:1<1::aid-cne1>3.3.co;2-4

Brochu, G., Maler, L., and Hawkes, R. (1990). Zebrin II: a polypeptide antigen expressed selectively by Purkinje cells reveals compartments in rat and fish cerebellum. J. Comp. Neurol. 291, 538-552. doi: 10.1002/cne.902910405

Carey, M. R., and Regehr, W. G. (2009). Noradrenergic control of associative synaptic plasticity by selective modulation of instructive signals. Neuron 62, 112-122. doi: 10.1016/j.neuron.2009.02.022

Chen, G., Hanson, C. L., and Ebner, T. J. (1996). Functional parasagittal compartments in the rat cerebellar cortex: an in vivo optical imaging study using neutral red. J. Neurophysiol. 76, 4169-4174.

Chockkan, V., and Hawkes, R. (1994). Functional and antigenic maps in the rat cerebellum: zebrin compartmentation and vibrissal receptive fields in lobule IXa. J. Comp. Neurol. 345, 33-45. doi: 10.1002/cne.903450103

Chung, S. H., Kim, C. T., and Hawkes, R. (2008). Compartmentation of GABA B receptor2 expression in the mouse cerebellar cortex. Cerebellum 7, 295-303. doi: $10.1007 /$ s12311-008-0030-3

Chung, H. J., Steinberg, J. P., Huganir, R. L., and Linden, D. J. (2003). Requirement of AMPA receptor GluR2 phosphorylation for cerebellar long-term depression. Science 300, 1751-1755. doi: 10.1126/science. 1082915

Coesmans, M., Weber, J. T., De Zeeuw, C. I., and Hansel, C. (2004). Bidirectional parallel fiber plasticity in the cerebellum under climbing fiber control. Neuron 44, 691-700. doi: 10.1016/j.neuron.2004.10.031 
Conn, P. J., and Pin, J. P. (1997). Pharmacology and functions of metabotropic glutamate receptors. Annu. Rev. Pharmacol. Toxicol. 37, 205-237. doi: 10. 1146/annurev.pharmtox.37.1.205

Consalez, G. G., and Hawkes, R. (2013). The compartmental restriction of cerebellar interneurons. Front. Neural Circuits 6:123. doi: 10.3389/fncir.2012.00123

Crépel, F., and Krupa, M. (1988). Activation of protein kinase C induces a longterm depression of glutamate sensitivity of cerebellar Purkinje cells. An in vitro study. Brain Res. 458, 397-401.

Croci, L., Barili, V., Chia, D., Massimino, L., van Vugt, R., Maserdotti, G., et al. (2011). Local insulin-like growth factor 1 expression is essential for Purkinje neuron survival at birth. Cell Death Diff. 18, 48-59. doi: 10.1038/cdd. 2010.78

Cummings, S. L. (1989). Distribution of corticotropin-releasing factor in the cerebellum and precerebellar nuclei of the cat. J. Comp. Neurol. 289, 657-675. doi: $10.1002 /$ cne. 902890410

Daniel, H., Levenes, C., and Crépel, F. (1998). Cellular mechanisms of cerebellar LTD. Trends Neurosci. 21, 401-407. doi: 10.1016/s0166-2236(98)01304-6

Dehnes, Y., Chaudry, F. A., Ullensvang, K., Lehre, K. P., Storm-Mathisen, J., and Danbolt, N. C. (1998). The glutamate transporter EAAT4 in rat cerebellar Purkinje cells: a glutamate-gated chloride concentrated near the synapse in parts of the dendritic membrane facing astroglia. J. Neurosci. 18, 3606-3619.

D’Ercole, A. J., Ye, P., Calikoglu, A. S., and Gutierrez-Ospina, G. (1996). The role of the insulin-like growth factors in the central nervous system. Mol. Neurobiol. 13, 227-255. doi: 10.1007/BF02740625

De Zeeuw, C. I., Hansel, C., Bian, F., Koekkoek, S. K., van Alphen, A. M., Linden, D. J., et al. (1998). Expression of a protein kinase C inhibitor in Purkinje cells blocks cerebellar LTD and adaptation of the vestibulo-ocular reflex. Neuron 20, 495-508. doi: 10.1016/s0896-6273(00)80990-3

Díez-Guerra, F. J. (2010). Neurogranin, a link between calcium/calmodulin and protein kinase C signaling in synaptic plasticity. IUBMB Life 62, 597-606. doi: 10.1002/iub.357

Ebner, T. J., Chen, G., Gao, W., and Reinert, K. (2005). Optical imaging of cerebellar functional architectures: parallel fiber beams, parasagittal bands and spreading acidification. Prog. Brain Res. 148, 125-138. doi: 10.1016/s0079-6123(04) 48011-x

Ebner, T. J., Wang, X., Gao, W., Cramer, S. W., and Chen, G. (2012). Parasagittal zones in the cerebellar cortex differ in excitability, information processing and synaptic plasticity. Cerebellum 11, 418-419. doi: 10.1007/s12311-011-0347-1

Empson, R. M., Buckby, L. E., Kraus, M., Bates, K. J., Crompton, M. R., Gundelfinger, E. D., et al. (2006). The cell adhesion molecule neuroplastin-65 inhibits hippocampal long-term potentiation via a mitogen-activated protein kinase p38-dependent reduction in surface expression of GluR1-containing glutamate receptors. J. Neurochem. 99, 850-860. doi: 10.1111/j.1471-4159.2006. 04123.x

Finch, E. A., Tanaka, K., and Augustine, G. J. (2012). Calcium as a trigger for cerebellar long-term synaptic depression. Cerebellum 11, 706-717. doi: 10. 1007/s12311-011-0314-x

Fletcher, C. F., Lutz, C. M., O’Sullivan, T. N., Shaughnessy, J. D. Jr., Hawkes, R., Frankel, W. N., et al. (1996). Absence epilepsy in tottering mutant mice is associated with calcium channel defects. Cell 87, 607-617. doi: 10.1016/s00928674(00)81381-1

Fritschy, J. M., and Panzanelli, P. (2006). Molecular and synaptic organization of GABAA receptors in the cerebellum: effects of targeted subunit gene deletions. Cerebellum 5, 275-285. doi: 10.1080/14734220600962805

Fritschy, J. M., Sidler, C., Parpan, F., Gassmann, M., Kaupmann, K., Bettler, B., et al. (2004). Independent maturation of the GABA (B) receptor subunits GABA (B1) and GABA (B2) during postnatal development in rodent brain. J. Comp. Neurol. 477, 235-252. doi: 10.1002/cne.20188

Furuichi, T., Yoshikawa, S., Miyawaki, A., Wada, K., Maeda, N., and Mikoshiba, K. (1989). Primary structure and functional expression of the inositol 1,4,5trisphosphate-binding protein P400. Nature 342, 32-38. doi: 10.1038/342032a0

Furutama, D., Morita, N., Takano, R., Sekine, Y., Sadakata, T., Shinoda, Y., et al. (2010). Expression of the IP3R1 promoter-driven nls-lacZ transgene in Purkinje cell parasagittal arrays of developing mouse cerebellum. J. Neurosci. Res. 88, 2810-2825. doi: 10.1002/jnr.22451

Furutama, D., Shimoda, K., Yoshikawa, S., Miyawaki, A., Furuichi, T., and Mikoshiba, K. (1996). Functional expression of the type 1 inositol 1,4,5trisphosphate receptor promoter-lacZ fusion genes in transgenic mice. J. Neurochem. 66, 1793-1801. doi: 10.1046/j.1471-4159.1996.66051793.x
Gao, W., Chen, G., Reinert, K. C., and Ebner, T. J. (2006). Cerebellar cortical molecular layer inhibition is organized in parasagittal zones. J. Neurosci. 26, 8377-8387. doi: 10.1523/jneurosci.2434-06.2006

Gao, Z., van Beugen, B. J., and De Zeeuw, C. I. (2012). Distributed synergistic plasticity and cerebellar learning. Nat. Rev. Neurosci. 13, 619-635. doi: 10. 1038/nrn3312

Gerendasy, D. D., and Sutcliffe, J. G. (1997). RC3/neurogranin, a postsynaptic calpacitin for setting the response threshold to calcium influxes. Mol. Neurobiol. 15, 131-163. doi: 10.1007/bf02740632

Graham, D. J., and Wylie, D. R. (2012). Zebrin-immunopositive and -immunonegative stripe pairs represent functional units in the pigeon vestibulocerebellum. J. Neurosci. 32, 12769-12779. doi: 10.1523/JNEUROSCI. 0197-12.2012

Gravel, C., Eisenman, L. E., Sasseville, R., and Hawkes, R. (1987). Parasagittal organization of the rat cerebellar cortex: a direct correlation between antigenic Purkinje cell bands revealed by mabQ73 and the organization of the olivocerebellar projection. J. Comp. Neurol. 265, 294-310. doi: 10.1002/cne.902650211

Gravel, C., and Hawkes, R. (1990). Parasagittal organization of the rat cerebellar cortex: direct comparison of Purkinje cell compartments and the organization of the spinocerebellar projection. J. Comp. Neurol. 291, 79-102. doi: 10.1002/cne. 902910107

Hallem, J. S., Thompson, J., Gundappa-Sulur, G., Hawkes, R., Bjaalie, J. G., and Bower, J. M. (1999). Spatial correspondence between tactile projection patterns and the distribution of the antigenic Purkinje cell markers anti-zebrin I and antizebrin II in the cerebellar folium crus IIa of the rat. Neuroscience 93, 1083-1094. doi: 10.1016/s0306-4522(99)00144-x

Hansel, C., de Jeu, M., Belmeguenai, A., Houtman, S. H., Buitendijk, G. H., Andreev, D., et al. (2006). $\alpha$ CaMKII is essential for cerebellar LTD and motor learning. Neuron 51, 835-843. doi: 10.1016/j.neuron.2006.08.013

Hansel, C., Linden, D. J., and D’Angelo, E. (2001). Beyond parallel fiber LTD: the diversity of synaptic and non-synaptic plasticity in the cerebellum. Nat. Neurosci. 4, 467-475.

Hawkes, R., Gallagher, E., and Ozol, K. (1997). Blebs in the mouse cerebellar granular layer as a sign of structural inhomogeneity. I. Anterior lobe vermis. Acta Anat. (Basel) 158, 205-214. doi: 10.1159/000147931

Hawkes, R., and Turner, R. W. (1994). Compartmentation of NADPH-diaphorase activity in the mouse cerebellar cortex. J. Comp. Neurol. 346, 499-516. doi: 10. 1002/cne.903460404

Hawkes, R. (1997). An anatomical model of cerebellar modules. Prog. Brain Res. 114, 39-52. doi: 10.1016/s0079-6123(08)63357-9

Hawkes, R., Beierbach, E., and Tan, S. S. (1999). Granule cell dispersion is restricted across transverse boundaries in mouse chimeras. Eur. J. Neurosci. 11, 3800-3808. doi: 10.1046/j.1460-9568.1999.00812.x

Hawkes, R., Colonnier, M., and Leclerc, N. (1985). Monoclonal antibodies reveal sagittal banding in the rodent cerebellar cortex. Brain Res. 333, 359-365. doi: 10. 1016/0006-8993(85)91593-8

Hawkes, R., Gallagher, E., and Ozol, K. (1998). Blebs in the mouse cerebellar granular layer as a sign of structural inhomogeneity. II. Posterior lobe vermis. Acta Anat. (Basel) 163, 47-55. doi: 10.1159/000046445

Hawkes, R., and Gravel, C. (1991). The modular cerebellum. Prog. Neurobiol. 36, 309-327. doi: 10.1016/0301-0082(91)90004-k

Hawkes, R., and Herrup, K. (1995). Aldolase C/zebrin II and the regionalization of the cerebellum. J. Mol. Neurosci. 6, 147-158. doi: 10.1007/bf02736761

Hawkes, R., and Leclerc, N. (1987). Antigenic map of the rat cerebellar cortex: the distribution of parasagittal bands as revealed by a monoclonal anti-Purkinje cell antibody mabQ73. J. Comp. Neurol. 256, 29-41. doi: 10.1002/cne.902560104

Hirano, T. (1991). Differential pre- and postsynaptic mechanisms for synaptic potentiation and depression between a granule cell and a Purkinje cell in rat cerebellar culture. Synapse 7, 321-323. doi: 10.1002/syn.890070408

Hirano, T. (2006). Cerebellar regulation mechanisms learned from studies on GluR82. Mol. Neurobiol. 33, 1-16. doi: 10.1385/mn:33:1:001

Huang, Y., Man, H. Y., Sekine-Aizawa, Y., Han, Y., Juluri, K., Luo, H., et al. (2005). $\mathrm{S}$-nitrosylation of $\mathrm{N}$-ethylmaleimide sensitive factor mediates surface expression of AMPA receptors. Neuron 46, 533-540. doi: 10.1016/j.neuron.2005.03.028

Ito, M. (1984). The Cerebellum and Neural Control. New York: Raven Press.

Ito, M. (1989). Long-term depression. Annu. Rev. Neurosci. 12, 85-102. doi: 10. 1146/annurev.ne.12.030189.000505

Ito, M. (2002). The molecular organization of cerebellar long-term depression. Nat. Rev. Neurosci. 3, 896-902. doi: 10.1038/nrn962 
Iwanuik, A. N., Marzban, H., Pakan, J. M. P., Watanabe, M., Hawkes, R., and Wylie, D. R. W. (2009). Compartmentation of the cerebellar cortex of hummingbirds (Aves: Trochilidae) revealed by the expression of zebrin II and phospholipase C $\beta 4$. J. Chem. Neuroanat. 37, 55-63. doi: 10.1016/j.jchemneu.2008. 10.001

Jörntell, H., and Hansel, C. (2006). Synaptic memories upside down: bidirectional plasticity at cerebellar parallel fiber-Purkinje cell synapses. Neuron 52, 227-238. doi: 10.1016/j.neuron.2006.09.032

Ji, Z., and Hawkes, R. (1994). Topography of Purkinje cell compartments and mossy fiber terminal fields in lobules II and III of the rat cerebellar cortex: spinocerebellar and cuneocerebellar projections. Neuroscience 61, 935-954. doi: 10.1016/0306-4522(94)90414-6

Kakegawa, W., and Yuzaki, M. (2005). A mechanism underlying AMPA receptor trafficking during cerebellar long-term potentiation. Proc. Natl. Acad. Sci. US A 102, 17846-17851. doi: 10.1073/pnas.0508910102

Kamikubo, Y., Tabata, T., Kakizawa, S., Kawakami, D., Watanabe, M., Ogura, A., et al. (2007). Postsynaptic $\mathrm{GABA}_{\mathrm{B}}$ receptor signalling enhances LTD in mouse cerebellar Purkinje cells. J. Physiol. 585, 549-563. doi: 10.1113/jphysiol.2007. 141010

Kano, M., Hashimoto, K., and Tabata, T. (2008). Type-1 metabotropic glutamate receptor in cerebellar Purkinje cells: a key molecule responsible for long-term depression, endocannabinoid signalling and synapse elimination. Philos. Trans. R. Soc. Lond. B Biol. Sci. 363, 2173-2186. doi: 10.1098/rstb.2008.2270

Karavanova, I., Vasudevan, K., Cheng, J., and Buonanno, A. (2007). Novel regional and developmental NMDA receptor expression patterns uncovered in NR2C subunit-beta-galactosidase knock-in mice. Mol. Cell Neurosci. 34, 468-480. doi: 10.1016/j.mcn.2006.12.001

Kashiwabuchi, N., Ikeda, K., Araki, K., Hirano, T., Shibuki, K., Takayama, C., et al. (1995). Impairment of motor coordination, Purkinje cell synapse formation and cerebellar long-term depression in GluR delta 2 mutant mice. Cell 81, 245-252. doi: 10.1016/0092-8674(95)90334-8

Kato, A. S., Knierman, M. D., Siuda, E. R., Isaac, J. T., Nisenbaum, E. S., and Bredt, D. S. (2012). Glutamate receptor $\delta 2$ associates with metabotropic glutamate receptor 1 (mGluR1), protein kinase $\mathrm{C} \gamma$, and canonical transient receptor potential 3 and regulates mGluR1-mediated synaptic transmission in cerebellar Purkinje neurons. J. Neurosci. 32, 15296-15308. doi: 10.1523/JNEUROSCI. 0705-12.2012.

Kaupmann, K., Huggel, K., Heid, J., Flor, P. J., Bischoff, S., Mickel, S. J., et al. (1997). Expression cloning of $\mathrm{GABA}_{\mathrm{B}}$ receptors uncovers similarity to metabotropic glutamate receptors. Nature 386, 239-246. doi: 10.1038/386239a0

Kim, E. C., Lee, M. J., Shin, S. Y., Seol, G. H., Han, S. H., Yee, J., et al. (2013). Phorbol 12-myristate 13-acetate enhances long-term potentiation in the hippocampus through activation of protein kinase $\mathrm{C} \delta$ and $\epsilon$. Korean J. Physiol. Pharmacol. 17, 51-56. doi: 10.4196/kjpp.2013.17.1.51

Knöpfel, T., and Grandes, P. (2002). Metabotropic glutamate receptors in the cerebellum with a focus on their function in Purkinje cells. Cerebellum 1, 1926. doi: $10.1007 / \mathrm{bf} 02941886$

Kulik, A., Nakadate, K., Nyíri, G., Notomi, T., Malitschek, B., Bettler, B., et al. (2002). Distinct localization of GABA(B) receptors relative to synaptic sites in the rat cerebellum and ventrobasal thalamus. Eur. J. Neurosci. 15, 291-307. doi: 10.1046/j.0953-816x.2001.01855.x

Larouche, M., Che, P. M., and Hawkes, R. (2006). Neurogranin expression identifies a novel array of Purkinje cell parasagittal stripes during mouse cerebellar development. J. Comp. Neurol. 494, 215-227. doi: 10.1002/cne.20791

Le, T. D., Shirai, Y., Okamoto, T., Tatsukawa, T., Nagao, S., Shimizu, T., et al. (2010). Lipid signaling in cytosolic phospholipase A2-alpha-cyclooxygenase-2 cascade mediates cerebellar long-term depression and motor learning. Proc. Natl. Acad. Sci. U S A 107, 3198-3203. doi: 10.1073/pnas.0915020107

Leclerc, N., Beesley, P. W., Brown, I., Colonnier, M., Gurd, J. W., Paladino, T., et al. (1989). Synaptophysin expression during synaptogenesis in the rat cerebellar cortex. J. Comp. Neurol. 280, 197-212. doi: 10.1002/cne.902800204

Leclerc, N., Gravel, C., and Hawkes, R. (1988). Development of parasagittal zonation in the rat cerebellar cortex. MabQ73 antigenic bands are created postnatally by the suppression of antigen expression in a subset of Purkinje cells. J. Comp. Neurol. 273, 399-420. doi: 10.1002/cne.902730310

Lev-Ram, V., Mehta, S. B., Kleinfeld, D., and Tsien, R. Y. (2003). Reversing cerebellar long-term depression. Proc. Natl. Acad. Sci. U S A 100, 15989-15993. doi: 10. 1073/pnas.2636935100
Lev-Ram, V., Nebyelul, Z., Ellisman, M. H., Huang, P. L., and Tsien, R. Y. (1997). Absence of cerebellar long-term depression in mice lacking neuronal nitric oxide synthase. Learn. Mem. 4, 169-177. doi: 10.1101/lm.4.1.169

Lev-Ram, V., Wong, S. T., Storm, D. R., and Tsien, R. Y. (2002). A new form of cerebellar long-term potentiation is postsynaptic and depends on nitric oxide but not cAMP. Proc. Natl. Acad. Sci. U S A 99, 8389-8393. doi: 10.1073/pnas. 122206399

Linden, D. J. (1995). Phospholipase A2 controls the induction of short-term versus long-term depression in the cerebellar Purkinje neuron in culture. Neuron 15, 1393-1401. doi: 10.1016/0896-6273(95)90017-9

Linden, D. J. (2001). The expression of cerebellar LTD in culture is not associated with changes in AMPA-receptor kinetics, agonist affinity, or unitary conductance. Proc. Natl. Acad. Sci. U S A 98, 14066-14071. doi: 10.1073/pnas. 241384598

Linden, D. J., and Connor, J. A. (1991). Participation of postsynaptic PKC in cerebellar long-term depression in culture. Science 254, 1656-1659. doi: 10. 1126/science.1721243

Linden, D. J., Dickinson, M. H., Smeyne, R., and Connor, J. A. (1991). A long-term depression of AMPA currents in cultured cerebellar Purkinje neurons. Neuron 7, 81-89. doi: 10.1016/0896-6273(91)90076-C

Luján, R., and Shigemoto, R. (2006). Localization of metabotropic GABA receptor subunits GABAB1 and GABAB2 relative to synaptic sites in the rat developing cerebellum. Eur. J. Neurosci. 23, 1479-1490. doi: 10.1111/j.1460-9568.2006. 04669.x

Möhler, H., and Fritschy, J. M. (1999). GABAB receptors make it to the top - as dimers. Trends Pharmacol. Sci. 20, 87-89. doi: 10.1016/s0165-6147(99)01323-1

Maeda, N., Niinobe, M., Inoue, Y., and Mikoshiba, K. (1989). Developmental expression and intracellular location of P400 protein characteristic of Purkinje cells in the mouse cerebellum. Dev. Biol. 133, 67-76. doi: 10.1016/00121606(89)90297-2

Marshall, F. H., Jones, K. A., Kaupmann, K., and Bettler, B. (1999). GABAB receptors - the first 7TM heterodimers. Trends Pharmacol. Sci. 20, 396-399. doi: 10.1016/s0165-6147(99)01383-8

Marzban, H., Chung, S. H., Kheradpezhouh, M., Feirabend, H., Watanabe, M., Voogd, J., et al. (2010). Antigenic compartmentation of the cerebellar cortex in the chicken (Gallus domesticus). J. Comp. Neurol. 518, 2221-2239. doi: 10. $1002 /$ cne. 22328

Marzban, H., Chung, S., Watanabe, M., and Hawkes, R. (2007). Phospholipase $\mathrm{C} \beta 4$ expression reveals the continuity of cerebellar topography through development. J. Comp. Neurol. 502, 857-871. doi: 10.1002/cne.21352

Marzban, H., and Hawkes, R. (2011). On the architecture of the posterior zone of the cerebellum. Cerebellum 10, 422-434. doi: 10.1007/s12311-010-0208-3

Marzban, H., Khanzada, U., Shabir, S., Hawkes, R., Langnaese, K., Smalla, K. H., et al. (2003). Expression of the immunoglobulin superfamily neuroplastin adhesion molecules in adult and developing mouse cerebellum and their localization to parasagittal stripes. J. Comp. Neurol. 462, 286-301. doi: 10.1002/cne.10719

Marzban, H., Sillitoe, R. V., Hoy, M., Chung, S. H., Rafuse, V. F., and Hawkes, R. (2004). Abnormal HNK-1 expression in the cerebellum of an N-CAM null mouse. J. Neurocytol. 33, 117-130. doi: 10.1023/b:neur.0000029652.96456.0d

Mateos, J. M., Benítez, R., Elezgarai, I., Azkue, J. J., Lázaro, E., Osorio, A., et al. (2000). Immunolocalization of the mGluR1b splice variant of the metabotropic glutamate receptor 1 at parallel fiber-Purkinje cell synapses in the rat cerebellar cortex. J. Neurochem. 74, 1301-1309. doi: 10.1046/j.1471-4159.2000.741301.x

Mateos, J. M., Osorio, A., Azkue, J. J., Benítez, R., Elezgarai, I., Bilbao, A., et al. (2001). Parasagittal compartmentalization of the metabotropic glutamate receptor mGluR1b in the cerebellar cortex. Eur. J. Anat. 5, 15-21.

Mathy, A., Ho, S. S., Davie, J. T., Duguid, I. C., Clark, B. A., and Häusser, M. (2009). Encoding of oscillations by axonal bursts in inferior olive neurons. Neuron 62, 388-399. doi: 10.1016/j.neuron.2009.03.023

Matsuda, S., Launey, T., Mikawa, S., and Hirai, H. (2000). Disruption of AMPA receptor GluR2 clusters following long-term depression induction in cerebellar Purkinje neurons. EMBO J. 19, 2765-2774. doi: 10.1093/emboj/19.12.2765

Mignery, G. A., Sudhof, T. C., Takei, K., and De Camilli, P. (1989). Putative receptor for inositol 1,4,5-triphosphate similar to ryanodine receptor. Nature 342, 192 195. doi: 10.1038/342192a0

Miyata, M., Okada, D., Hashimoto, K., Kano, M., and Ito, M. (1999). Corticotropin-releasing factor plays a permissive role in cerebellar long-term depression. Neuron 22, 763-775. doi: 10.1016/s0896-6273(00)80735-7 
Mugnaini, E., Berrebi, A. S., Dahl, A. L., and Morgan, J. I. (1987). The polypeptide PEP-19 is a marker for Purkinje neurons in cerebellar cortex and cartwheel neurons in the dorsal cochlear nucleus. Arch. Ital. Biol. 126, 41-67.

Newton, A. C. (1995). Protein kinase C: structure, function, and regulation. J. Biol. Chem. 270, 28495-28498. doi: 10.1074/jbc.270.48.28495

Oberdick, J., Schilling, K., Smeyne, R. J., Corbin, J. G., Bocchiaro, C., and Morgan, J. I. (1993). Control of segment-like patterns of gene expression in the mouse cerebellum. Neuron 10, 1007-1018. doi: 10.1016/0896-6273(93) 90050-2

Oscarsson, O. (1979). Functional units of the cerebellum- sagittal zones and microzones. Trends Neurosci. 2, 143-145. doi: 10.1016/0166-2236(79) 90057-2

Overbeck, T. L., and King, J. S. (1999). Developmental expression of corticotropinreleasing factor in the postnatal murine cerebellum. Brain Res. Dev. Brain Res. 115, 145-159. doi: 10.1016/s0165-3806(99)00059-0

Ozol, K. O., and Hawkes, R. (1997). The compartmentation of the granular layer of the cerebellum. Histol. Histopathol. 12, 171-184.

Pak, J. H., Huang, F. L., Li, J., Balschun, D., Reymann, K. G., Chiang, C., et al. (2000). Involvement of neurogranin in the modulation of calcium/calmodulindependent protein kinase II, synaptic plasticity and spatial learning: a study with knockout mice. Proc. Natl. Acad. Sci. U S A 97, 11232-11237. doi: 10.1073/pnas. 210184697

Pakan, J. M., Iwaniuk, A. N., Wylie, D. R., Hawkes, R., and Marzban, H. (2007). Purkinje cell compartmentation as revealed by zebrin II expression in the cerebellar cortex of pigeons (Columba livia). J. Comp. Neurol. 501, 619-630. doi: 10.1002/cne.21266

Paukert, M., Huang, Y. H., Tanaka, K., Rothstein, J. D., and Bergles, D. E. (2010). Zones of enhanced glutamate release from climbing fibers in the mammalian cerebellum. J. Neurosci. 30, 7290-7299. doi: 10.1523/jneurosci.5118-09.2010

Piochon, C., Levenes, C., Ohtsuki, G., and Hansel, C. (2010). Purkinje cell NMDA receptors assume a key role in synaptic gain control in the mature cerebellum. J. Neurosci. 30, 15330-15335. doi: 10.1523/jneurosci.4344-10.2010

Ruigrok, T. J. (2011). Ins and outs of cerebellar modules. Cerebellum 10, 464-474. doi: 10.1007/s12311-010-0164-y

Safo, P. K., Cravatt, B. F., and Regehr, W. G. (2006). Retrograde endocannabinoid signaling in the cerebellar cortex. Cerebellum 5, 134-145. doi: 10 . 1080/14734220600791477

Sarna, J. R., Marzban, H., Watanabe, M., and Hawkes, R. (2006). Complementary stripes of phospholipase $\mathrm{C} \beta 3$ and $\mathrm{C} \beta 4$ expression by Purkinje cell subsets in the mouse cerebellum. J. Comp. Neurol. 496, 303-313. doi: 10.1002/cne.20912

Sawada, K., Fukui, Y., and Hawkes, R. (2008). Spatial distribution of corticotropinreleasing factor immunopositive climbing fibers in the mouse cerebellum: analysis by whole mount immunocytochemistry. Brain Res. 1222, 106-117. doi: 10.1016/j.brainres.2008.05.029

Schilling, K., Schmidt, H. H., and Baader, S. L. (1994). Nitric oxide synthase expression reveals compartments of cerebellar granule cells and suggests a role for mossy fibers in their development. Neuroscience 59, 893-903. doi: 10 1016/0306-4522(94)90293-3

Schonewille, M., Belmeguenai, A., Koekkoek, S. K., Houtman, S. H., Boele, H. J., van Beugen, B. J., et al. (2010). Purkinje cell-specific knockout of the protein phosphatase PP2B impairs potentiation and cerebellar motor learning. Neuron 67, 618-628. doi: 10.1016/j.neuron.2010.07.009

Schonewille, M., Gao, Z., Boele, H. J., Veloz, M. F., Amerika, W. E., Simek, A. A., et al. (2011). Reevaluating the role of LTD in cerebellar motor learning. Neuron 70, 43-50. doi: 10.1016/j.neuron.2011.02.044

Seil, F. J., Johnson, M. L., and Hawkes, R. (1995). Molecular compartmentation expressed in cerebellar cultures in the absence of neuronal activity and neuronglia interactions. J. Comp. Neurol. 356, 398-407. doi: 10.1002/cne.903560307

Shearman, M. S., Naor, Z., Sekiguchi, K., Kishimoto, A., and Nishizuka, Y. (1989). Selective activation of the $\gamma$-subspecies of protein kinase $C$ from bovine cerebellum by arachidonic acid and its lipoxygenase metabolites. FEBS Lett. 243, 177-182. doi: 10.1016/0014-5793(89)80125-5

Shin, J. H., and Linden, D. J. (2005). An NMDA receptor/nitric oxide cascade is involved in cerebellar LTD but is not localized to the parallel fiber terminal. $J$. Neurophysiol. 94, 4281-4289. doi: 10.1152/jn.00661.2005

Shirai, Y., and Ito, M. (2004). Specific differential expression of phospholipase A2 subtypes in rat cerebellum. J. Neurocytol. 33, 297-307. doi: 10.1023/b:neur. 0000044191.83858.f7
Sillitoe, R. V., Benson, M. A., Blake, D. J., and Hawkes, R. (2003). Abnormal dysbindin expression in cerebellar mossy fiber synapses in the $m d x$ mouse model of Duchenne muscular dystrophy. J. Neurosci. 23, 6576-6585.

Sillitoe, R. V., Marzban, H., Larouche, M., Zahedi, S., Affanni, J., and Hawkes, R. (2005). Conservation of the architecture of the anterior lobe vermis of the cerebellum across mammalian species. Prog. Brain Res. 148, 283-297. doi: 10. 1016/s0079-6123(04)48022-4

Sugihara, I., and Quy, P. N. (2007). Identification of aldolase C compartments in the mouse cerebellar cortex by olivocerebellar labeling. J. Comp. Neurol. 500, 1076-1092. doi: 10.1002/cne.21219

Sugihara, I., and Shinoda, Y. (2004). Molecular, topographic and functional organization of the cerebellar cortex: a study with combined aldolase C and olivocerebellar labeling. J. Neurosci. 24, 8771-8785. doi: 10.1523/jneurosci.196104.2004

Tabata, T., Araishi, K., Hashimoto, K., Hashimotodani, Y., van der Putten, H., Bettler, B., et al. (2004). Ca2+ activity at GABAB receptors constitutively promotes metabotropic glutamate signaling in the absence of GABA. Proc. Natl. Acad. Sci. U S A 101, 16952-16957. doi: 10.1073/pnas.0405387101

Tanaka, S., Kawaguchi, S. Y., Shioi, G., and Hirano, T. (2013). Long-term potentiation of inhibitory synaptic transmission onto cerebellar Purkinje neurons contributes to adaptation of vestibulo-ocular reflex. J. Neurosci. 33, 1720917220. doi: 10.1523/jneurosci.0793-13.2013

Tanaka, C., and Nishizuka, Y. (1994). The protein kinase C family for neuronal signaling. Annu. Rev. Neurosci. 17, 551-567. doi: 10.1146/annurev.neuro.17.1.551

Terada, N., Banno, Y., Ohno, N., Fujii, Y., Murate, T., Sarna, J. R., et al. (2004). Compartmentation of the mouse cerebellar cortex by sphingosine kinase. J. Comp. Neurol. 469, 119-127. doi: 10.1002/cne.11002

Torres-Aleman, I., Pons, S., and Arévalo, M. A. (1994). The insulin-like growth factor I system in the rat cerebellum: developmental regulation and role in neuronal survival and differentiation. J. Neurosci. Res. 39, 117-126. doi: 10. 1002/jnr.490390202

Tsuruno, S., Kawaguchi, S. Y., and Hirano, T. (2008). Src-family protein tyrosine kinase negatively regulates cerebellar long-term depression. Neurosci. Res. 61, 329-332. doi: 10.1016/j.neures.2008.03.004

Turgeon, S. M., and Albin, R. L. (1993). Pharmacology, distribution, cellular localisation and development of $\mathrm{GABA}_{\mathrm{B}}$ binding in rodent cerebellum. Neuroscience 55, 311-323. doi: 10.1016/0306-4522(93)90501-6

Vogt, K. E., and Canepari, M. (2010). On the induction of postsynaptic granule cell-Purkinje neuron LTP and LTD. Cerebellum 9, 284-290. doi: 10.1007/s12311010-0174-9

Voogd, J., Pardoe, J., Ruigrok, T. J., and Apps, R. (2003). The distribution of climbing and mossy fiber collateral branches from the copula pyramidis and the paramedian lobule: congruence of climbing fiber cortical zones and the pattern of zebrin banding within the rat cerebellum. J. Neurosci. 23, 4645-4656.

Voogd, J., and Ruigrok, T. J. (2004). The organization of the corticonuclear and olivocerebellar climbing fiber projections to the rat cerebellar vermis: the congruence of projection zones and the zebrin pattern. J. Neurocytol. 33, 5-21. doi: 10.1023/b:neur.0000029645.72074.2b

Wadiche, J. I., and Jahr, C. E. (2001). Multivesicular release at climbing fiberPurkinje cell synapses. Neuron 32, 301-313. doi: 10.1016/s0896-6273(01) 00488-3

Wadiche, J. I., and Jahr, C. E. (2005). Patterned expression of Purkinje cell glutamate transporters controls synaptic plasticity. Nat. Neurosci. 8, 1329-1334. doi: $10.1038 / \mathrm{nn} 1539$

Wang, X., Chen, G., Gao, W., and Ebner, T. (2009). Long-term potentiation of the responses to parallel fiber stimulation in mouse cerebellar cortex in vivo. Neuroscience 162, 713-722. doi: 10.1016/j.neuroscience.2009.01.071

Wang, X., Chen, G., Gao, W., and Ebner, T. J. (2011). Parasagittally aligned, mGluR1-dependent patches are evoked at long latencies by parallel fiber stimulation in the mouse cerebellar cortex in vivo. J. Neurophysiol. 105, 1732-1746. doi: 10.1152/jn.00717.2010

Wassef, M., Cholley, B., Heizmann, C. W., and Sotelo, C. (1992). Development of the olivocerebellar projection in the rat: II. Matching of the developmental compartmentations of the cerebellum and inferior olive through the projection map. J. Comp. Neurol. 323, 537-550. doi: 10.1002/cne.903230406

Wassef, M., Sotelo, C., Thomasset, M., Granholm, A. C., Leclerc, N., Rafrafi, J., et al. (1990). Expression of compartmentation antigen zebrin I in cerebellar transplants. J. Comp. Neurol. 294, 223-234. doi: 10.1002/cne.902940207 
Wei, P., Blundon, J. A., Rong, Y., Zakharenko, S. S., and Morgan, J. I. (2011). Impaired locomotor learning and altered cerebellar synaptic plasticity in pep19/pcp4-null mice. Mol. Cell. Biol. 31, 2838-2844. doi: 10.1128/mcb.05208-11

Welker, W. (1987). "Spatial organization of somatosensory projections to granule cell cerebellar cortex: functional and connectional implications of fractured somatotopy (summary of Wisconsin studies)," in New Concepts in Cerebellar Neurobiology, ed J. S. King (New York: Alan R. Liss Inc.), 239-280.

Yan, X. X., Yen, L. S., and Garey, L. J. (1993). Parasagittal patches in the granular layer of the developing and adult rat cerebellum as demonstrated by NADPHdiaphorase histochemistry. Neuroreport 4, 1227-1230. doi: 10.1097/00001756199309000-00004

Zagrebelsky, M., Rossi, F., Hawkes, R., and Strata, P. (1996). Topographically organised climbing fibre sprouting in the adult mammalian cerebellum. Eur. J. Neurosci. 8, 1051-1054. doi: 10.1111/j.1460-9568.1996.tb01591.x

Zagrebelsky, M., Rossi, F., Hawkes, R., and Strata, P. (1997). Reestablishment of the olivocerebellar projection map by compensatory transcommissural reinnervation following unilateral transection of the inferior cerebellar peduncle in the newborn rat. J. Comp. Neurol. 379, 283-299. doi: 10.1002/(sici)1096-9861 (19970310)379:2<283::aid-cne9>3.0.co;2-\#
Zuo, J., De Jager, P. L., Takahashi, K. A., Jiang, W., Linden, D. J., and Heintz, N. (1997). Neurodegeneration in Lurcher mice caused by mutation in $\delta 2$ glutamate receptor gene. Nature 388, 769-773. doi: 10.1038/42009

Conflict of Interest Statement: The author declares that the research was conducted in the absence of any commercial or financial relationships that could be construed as a potential conflict of interest.

Received: 13 December 2013; accepted: 07 March 2014; published online: 28 March 2014.

Citation: Hawkes R (2014) Purkinje cell stripes and long-term depression at the parallel fiber-Purkinje cell synapse. Front. Syst. Neurosci. 8:41. doi: 10.3389/fnsys.2014.00041 This article was submitted to the journal Frontiers in Systems Neuroscience.

Copyright (C) 2014 Hawkes. This is an open-access article distributed under the terms of the Creative Commons Attribution License (CC BY). The use, distribution or reproduction in other forums is permitted, provided the original author(s) or licensor are credited and that the original publication in this journal is cited, in accordance with accepted academic practice. No use, distribution or reproduction is permitted which does not comply with these terms. 